\title{
Control of Citrus Huanglongbing via Trunk Injection of Plant Defense Activators and Antibiotics
}

\author{
J. Hu, J. Jiang, and N. Wang ${ }^{\dagger}$
}

First author: Citrus Research and Education Center, Department of Microbiology and Cell Science, Institute of Food and Agricultural Sciences, University of Florida, Lake Alfred 33850; second author: College of Agronomy, Jiangxi Agricultural University, Nanchang 330045, China; and third author: China-USA Citrus Huanglongbing Joint Laboratory (A joint laboratory of The University of Florida's Institute of Food and Agricultural Sciences and Gannan Normal University), National Navel Orange Engineering Research Center, Gannan Normal University, Ganzhou, Jiangxi, China; Citrus Research and Education Center, Department of Microbiology and Cell Science, IFAS, University of Florida, Lake Alfred, FL. Current address of J. Hu: School of Plant Sciences, University of Arizona, Tucson 85721.

Accepted for publication 13 September 2017.

\begin{abstract}
Citrus huanglongbing (HLB) or greening is a devastating disease of citrus worldwide and no effective control measure is currently available. Plant defense activators environmentally friendly compounds capable of inducing resistance against many plant pathogens. Earlier studies showed that foliar spray of plant defense inducers could slow down HLB disease progress. In this study, eight plant defense activators and three antibiotics were evaluated in three field trials for their effect to control HLB by trunk injection of young and mature sweet orange trees. Results showed that four trunk injections of several activators, including salicylic acid, oxalic acid, acibenzolar-S-methyl, and potassium phosphate, provided significant control of HLB by suppressing 'Candidatus Liberibacter asiaticus' titer and disease progress. Trunk injection of penicillin, streptomycin, and oxytetracycline hydrochloride resulted in

excellent control of HLB. In general, antibiotics were more effective in reduction of ' $\mathrm{Ca}$. L. asiaticus' titer and HLB symptom expressions than plant defense activators. These treatments also resulted in increased yield and better fruit quality. Injection of both salicylic acid and acibenzolar-S-methyl led to significant induction of pathogenesis-related $(P R)$ genes $P R-1$ and $P R-2$ genes. Meanwhile, injection of either potassium phosphate or oxalic acid resulted in significant induction of $P R-2$ or $P R-15$ gene expression, respectively. These results suggested that HLB diseased trees remained inducible for systemic acquired resistance under field conditions. In summary, this study presents information regarding controlling HLB via trunk injection of plant defense activators and antibiotics, which helps citrus growers in decision making regarding developing an effective HLB management program.
\end{abstract}

Citrus huanglongbing (HLB) or greening is one of the most destructive diseases of citrus and causes significant economic losses worldwide (Bove 2006; da Graca and Korsten 2004; Gottwald et al. 2007). Citrus HLB in Florida is associated with 'Candidatus Liberibacter asiaticus', a phloem-limiting bacterium vectored by Asian citrus psyllid (ACP) Diaphorina citri (Halbert and Manjunath 2004). All commercial citrus cultivars are susceptible to HLB and symptom expression on ' $\mathrm{Ca}$. L. asiaticus'-infected trees varies widely, including yellow shoot, blotchy leaf mottle, vein corking, nutrient deficient foliage, premature fruit drop, small lopsided fruit with off-flavor, twig dieback, and tree death (da Graca and Korsten 2004; Halbert and Manjunath 2004). HLB-diseased trees have an average yield loss of 30 to $100 \%$ and often die in 5 to 8 years after diagnosis (Bove 2006). Currently, it has been estimated that almost all mature citrus trees have been infected by ' $\mathrm{Ca}$. L. asiaticus' in Florida.

Citrus HLB in Florida is currently mitigated by disrupting ' $\mathrm{Ca}$. $\mathrm{L}$. asiaticus' transmission through ACP control (Boina and Bloomquist 2015). Psyllid control with insecticides combined with foliar nutritional spray has kept ACP populations at low levels, slowed spread of the disease, and maintained yield potential in orchards with high incidence of HLB (Stansly et al. 2014). However, such an HLB management program has not been able to stop HLB from spreading to new plantings (Boina and Bloomquist 2015; Stansly et al. 2014). Several new control tactics such as thermotherapy (Hoffman et al. 2013), chemotherapy (Hu and Wang 2016; Zhang et al. 2014), and transgenic citrus (Mirkov and Gonzalez-Ramos

${ }^{\dagger}$ Corresponding author: N. Wang; E-mail: nianwang@ufl.edu

(c) 2018 The American Phytopathological Society
2013) are in the early stage of development and are likely years away from application in the field. Considering the limited chemical options for controlling bacterial plant diseases in agricultural settings, there are urgent needs to search for better options to expand HLB control arsenal.

Induced resistance, especially systemic acquired resistance (SAR), has been reported to be useful to control many plant diseases (Buzi et al. 2004; Dekkers et al. 2004; Graham and Myers 2011; Justyna and Ewa 2013; Mersha et al. 2012; Obanor et al. 2013; Oren and Yogev 2002; Perez et al. 2003). The SAR mechanism involves a specific defense signaling pathway that requires the signal molecule salicylic acid (SA) and is associated with accumulation of pathogenesis-related (PR) proteins. SAR may be activated by either the presence of a pathogen or spraying plants with chemical inducers or activators (Aranega-Bou et al. 2014; Vallad and Goodman 2004). Multiple plant defense activators such as acibenzolar-S-methyl (ASM), $\beta$-aminobutyric, benzothiadiazole, 2,6-dichloro-isonicotinic acid, (INA) and phosphite have been evaluated extensively for their efficacy on disease control under field conditions (Vallad and Goodman 2004; Walters et al. 2013). Results from the majority of earlier studies showed that SAR inducers provided good but often-incomplete protection against a wide variety of pathogens. Their utility for practical application in disease management has been questioned because of large variability in effectiveness of control. For example, disease reduction by plant defense activators under field conditions could vary from lack of control to $99 \%$ and also from field to field (Vallad and Goodman 2004; Walters et al. 2013). Such relatively large variability in their efficacy is thought to be influenced by several factors, including pathogen, plant species, host genotype, plant nutrition, and environmental conditions, as well as application time, frequency, and method. This variability highlights the 
importance of evaluating plant defense activators under local environmental conditions and optimization of application.

Previous research on citrus demonstrated that SAR in citrus was highly inducible and treatment of citrus plants with several plant defense activators resulted in enhanced resistance to both bacterial and fungal diseases. For example, foliar spray of citrus with benzothiadiazole induced resistance to citrus scab, melanose, and Alternaria brown spot (Agostini et al. 2003). Soil application of ASM, INA, and imidacloprid increased expression of gene $P R-2$ and provided effective control of citrus canker in greenhouse assays (Francis et al. 2009). Furthermore, soil-applied ASM, thiamethoxam, and imidacloprid provided effective protection from canker on foliar flushes of young grapefruit trees under epidemic conditions; however, the efficacy depended on rate, frequency, and timing of application (Graham and Myers 2011). A recent study of citrus revealed that foliar sprays of INA, $\beta$-aminobutyric, and benzothiadiazole, individually or in combination, were effective in slowing down progress of HLB disease ( $\mathrm{Li}$ et al. 2016a). Some of these studies noted that application methods greatly affected activators' effectiveness in disease control, with soil application superior to foliar spray (Dekkers et al. 2004; Francis et al. 2009; Graham and Leite 2004; Graham and Myers 2011). Therefore, optimizing application methods may result in better treatment effects.

Trunk injection is a target-precise method for efficient delivery of compounds into the plant by harnessing the xylem's quick transporting ability. There has been limited research on trunk injection of antibiotics and plant defense activators for better disease control. Currently, the utility of trunk injection of bactericides and plant defense activators in disease management has been demonstrated by several recent field studies. Aćimović et al. (2015) showed that one to two apple tree injection of potassium phosphite and ASM provided good control of blossom and shoot blight (Aćimović et al. 2015). Our previous study demonstrated that oxytetracycline injection provided long-lasting suppression of ' $\mathrm{Ca}$. L. asiaticus' populations in ' $\mathrm{Ca}$. L. asiaticus'-infected trees and prevented further tree decline by promoting symptomless new growth (Hu and Wang 2016). As part of an ongoing project to evaluate trunk injection of SAR activators and antibiotics for better control of citrus HLB, we conducted multiyear field trials to ascertain the utility of eight activators and three antibiotics on suppression of ' $\mathrm{Ca}$. L. asiaticus' titers and HLB disease progress in citrus under natural field conditions.

\section{MATERIALS AND METHODS}

Treatments of plant defense activators and antibiotics. The chemical inducers tested in field trials consisted of SA, oxalic acid (OA), potassium phosphate dibasic (PHI), ASM (Actigard 50 WP; Syngenta), imidacloprid (IMI) (AmTide imidacloprid 2F;
AmTide LLC), L-ascorbic acid sodium salt (AA) (500GR; Acrōs Organics), $\beta$-aminobutyric acid (BABA) (Sigma-Aldrich), and INA (Astatech Inc.). Antibiotics tested in this study included oxytetracycline hydrochloride (OTC) (Arbor-OTC formulation; Arborjet Inc.), penicillin G sodium salt (PCN) (Sigma-Aldrich), and streptomycin sulfate salt (STM) (Sigma-Aldrich). The concentration and injection volume for each treatment are summarized in Table 1.

Field sites and experimental design. Three field trials were independently conducted in a Mid-Florida Foundation grove located in central Florida from 2014 to 2016. The grove is established on the well-drained soil of Astatula fine sand (Typic Quartzipsamment) and naturally infected by ' $\mathrm{Ca}$. L. asiaticus', with HLB severity less than $30 \%$. All HLB-affected trees received standard commercial care, including normal irrigation and fertilization as well as conventional pest management practices. A randomized complete block design was used for all three trials. Two weeks prior to the start of each trial, a field survey was carried out to determine the HLB severity of individual trees via visual assessment and ' $\mathrm{Ca}$. L. asiaticus' titers using a real-time quantitative polymerase chain reaction (qPCR) assay. Trees with a similar stage of HLB symptom expression were selected and divided into blocks (blocking factor) according to the level of ' $\mathrm{Ca}$. L. asiaticus' titers in an HLB-affected tree. Trials I and II consisted of four blocks of 12 and 9 treatments, randomly assigned to 5-yearold Hamlin sweet orange (Citrus sinensis L. Osbeck) on cultivar Swingle citrumelo rootstock. Trial III had 10 blocks of six treatments randomly assigned to 11-year-old Midsweet orange $(C$. sinensis L. Osbeck) on cultivar Carrizo citrange rootstock. To achieve uniform distribution across the tree canopy, higher injection volumes $(300 \mathrm{ml})$ were used in trial III as compared with an injection volume of $200 \mathrm{ml}$ in trials I and II.

Treatment applications via trunk injections. Two injection ports per tree, placed at the opposite side of a tree trunk and positioned at approximately $15 \mathrm{~cm}$ above the bud union, were made by drilling 20 to $30 \mathrm{~mm}$ into the xylem tissue with a 7.14- $\mathrm{mm}$ drill bit. Ports were properly sealed with and Arborplug number 3 using Arborplug setter and a rubber hammer (Arborjet Inc.). Treatment liquid in a pressurized bottle was injected into each port on a tree using Arborjet tree I.V. Micro Infusion at the recommended pressure ( $<50 \mathrm{psi}$ ) during a warm and sunny day ( $\mathrm{Hu}$ and Wang 2016). The area surrounding the drilling site was treated with Ridomil gold (Novartis) to prevent opportunistic infection by Phytophthora spp. Trunk injections of different treatments were conducted when new flush was present. In all three trials, four injections were carried out on an approximately 3-month basis. Trial I started in June 2014 and ended in October 2015; trial II started in September 2014 and ended in October 2015; and trial III started in February 2015 to February 2016.

TABLE 1. Concentrations and dosages of plant defense activators and antibiotics used for trunk injection ${ }^{\mathrm{a}}$

\begin{tabular}{|c|c|c|c|c|c|c|c|c|}
\hline \multicolumn{3}{|c|}{ Trial I } & \multicolumn{3}{|c|}{ Trial II } & \multicolumn{3}{|c|}{ Trial III } \\
\hline Treatments & Rate $(\mathrm{mg} / \mathrm{ml})$ & Volume $(\mathrm{ml} /$ tree $)$ & Treatments & Rate $(\mathrm{mg} / \mathrm{ml})$ & Volume (ml/tree) & Treatments & Rate $(\mathrm{mg} / \mathrm{ml})$ & Volume ( $\mathrm{ml} /$ tree $)$ \\
\hline $\mathrm{T} 1=\mathrm{WIC}$ & NA & 200 & $\mathrm{~T} 1=\mathrm{WIC}$ & NA & 200 & $\mathrm{~T} 1=\mathrm{WIC}$ & NA & 300 \\
\hline $\mathrm{T} 3=\mathrm{SA}$ & 4 & 200 & $\mathrm{~T} 5=\mathrm{SA}$ & 4 & 200 & $\mathrm{~T} 3=\mathrm{SA}$ & 3 & 300 \\
\hline $\mathrm{T} 2=\mathrm{OA}$ & 5 & 200 & $\mathrm{~T} 4=\mathrm{OA}$ & 5 & 200 & $\mathrm{~T} 2=\mathrm{OA}$ & 5 & 300 \\
\hline $\mathrm{T} 5=\mathrm{PHI}$ & 5 & 200 & $\mathrm{~T} 6=\mathrm{PHI}$ & 5 & 200 & $\mathrm{~T} 4=\mathrm{PHI}$ & 3 & 300 \\
\hline $\mathrm{T} 6=\mathrm{IMI}$ & 5 & 200 & $\mathrm{~T} 7$ = IMI & 5 & 200 & $\mathrm{~T} 6=\mathrm{OTC}+\mathrm{STM}$ & 4 & 300 \\
\hline $\mathrm{T} 9=\mathrm{STM}$ & 12.5 & 200 & $\mathrm{~T} 2=\mathrm{BABA}$ & 5 & 200 & $\ldots$ & $\ldots$ & $\ldots$ \\
\hline $\mathrm{T} 10=\mathrm{STM}$ & 6.25 & 200 & T9 = INA & 5 & 200 & $\ldots$ & $\ldots$ & $\ldots$ \\
\hline $\mathrm{T} 11=\mathrm{OTC}$ & 12.5 & 200 & $\ldots$ & $\ldots$ & $\ldots$ & $\ldots$ & $\ldots$ & $\ldots$ \\
\hline $\mathrm{T} 12=\mathrm{OTC}$ & 6.25 & 200 & $\ldots$ & $\ldots$ & $\ldots$ & $\ldots$ & $\ldots$ & $\ldots$ \\
\hline
\end{tabular}

a $\mathrm{WIC}=$ water as control, $\mathrm{NA}=$ not applicable, $\mathrm{SA}=$ salicylic acid, $\mathrm{ASM}=$ acibenzolar-S-methyl, $\mathrm{OA}=\mathrm{oxalic}$ acid, $\mathrm{PHI}=$ potassium phosphite, $\mathrm{PCN}=$ penicillin $\mathrm{G}$ sodium salt, $\mathrm{STM}=$ streptomycin, $\mathrm{OTC}=$ oxytetracycline hydrochloride, $\mathrm{AA}=\mathrm{L}$-ascorbic acid sodium salt, $\mathrm{BABA}=\beta$-aminobutyric acid, and $\mathrm{INA}=2$, 6-dichloro-isonicotinic acid. 
Disease assessment, fruit yield, and quality analysis. Visual assessments of disease severity were conducted on a 3-month interval using the HLB severity scale described by Gottwald et al. (2007). Each individual tree canopy was divided horizontally and vertically into eight sections and disease severity was scored on a section basis on a scale from 0 to 5 , where $0=$ none and $1=\leq 20,2=21$ to $40,3=$ 41 to $60,4=61$ to 80 , and $5=81$ to $100 \%$ of limbs affected. Mean HLB score was obtained by averaging these eight scores of an individual tree, which was used to calculate the amount of disease severity, expressed as the standardized area under the disease progress stair (sAUDPS) using Simko and Piepho's formula (Simko and Piepho 2012).

Fruit were harvested and weighed in October 2015 for trials I and II and in February 2016 for trial III. The yield data were recorded for each tree and a composite fruit sample (approximately $8 \mathrm{~kg}$ ) was randomly sampled from each tree and subjected to juice quality analysis using a standard procedure (Gottwald et al. 2012). Juice content and fruit acidity were expressed as percent juice and percent citric acid. Total soluble solids expressed as fruit brix, a measure of sugar content in fruit, were calculated as weight (grams) of sugar in $100 \mathrm{~g}$ of juice. Thereafter, fruit brix and acidity ratio were calculated accordingly. All fruit from trees receiving antibiotic treatment were destroyed after data collection.

DNA isolation and ' $\mathrm{Ca}$. L. asiaticus' titer enumerations. Due to the uneven distribution of the ' $\mathrm{Ca}$. L. asiaticus' bacterium throughout the tree canopy, three sets of composite leaf samples (four leaves with mottling symptoms per limb) were collected from three different limbs of a tree canopy at a given time point. The first set of leaf samples was collected approximately 2 weeks prior to start of the first trunk injection. Thereafter, the same set of three limbs were repeatedly sampled 1 week after each treatment application. Leaf samples were placed in a polyethylene bag on ice and transported back to the lab for DNA extraction. Midribs were minced and $100 \mathrm{mg}$ of minced midrib tissue was frozen in liquid nitrogen and ground using the bead-beating method with Qiagen Tissue Lyser II (Retsch, Inc.). DNA was isolated from ground tissue using the Wizard Genomic DNA purification kit (Promega Corp.) according to the manufacturer's protocol. The airdried DNA pellet was dissolved in $100 \mu \mathrm{l}$ of DNA rehydration solution. The concentration of isolated DNA was estimated on a NanoDrop ND-1000 spectrophotometer (NanoDrop Technologies) and adjusted to $100 \mathrm{ng} / \mu \mathrm{l}$. An aliquot of $4 \mu \mathrm{l}$ was used as DNA template to determine the ' $\mathrm{Ca}$. L. asiaticus' titers using a real-time qPCR method (Wang et al. 2006). All qPCR were performed in triplicate on an ABI PRISM 7500 sequence detection system (Applied Biosystems), with cycling conditions described previously (Hu and Wang 2016). Specifically, a 25- $\mu$ l qPCR consisted of $12.5 \mu \mathrm{l}$ of $2 \times$ QuantiTect probe PCR master mix (Qiagen), $1.25 \mu \mathrm{l}$ of each primer $(10 \mu \mathrm{M}), 0.5 \mu \mathrm{l}$ of probe $(10 \mu \mathrm{M}), 4 \mu \mathrm{l}$ of DNA template, and $5.5 \mu \mathrm{l}$ of DNase/RNase-free water. The PCR cycling conditions consisted of an initial activation step at $95^{\circ} \mathrm{C}$ for $15 \mathrm{~min}$, followed by 40 cycles of $94^{\circ} \mathrm{C}$ for $15 \mathrm{~s}$ and $60^{\circ} \mathrm{C}$ for $1 \mathrm{~min}$. Cycle threshold $\left(\mathrm{C}_{\mathrm{t}}\right)$ values were obtained by adjusting the threshold to 0.02 , as recommended by the QuantiTect Probe PCR Kits (Qiagen). $\mathrm{A} \mathrm{C}_{\mathrm{t}}$ value was converted into ' $\mathrm{Ca}$. L. asiaticus' titers as genome copy number using a standard curve described previously (Trivedi et al. 2009). To determine the effect of treatments on ' $\mathrm{Ca}$. L. asiaticus' titers in leaves, treatment effect was expressed as percent change in ' $\mathrm{Ca}$. L. asiaticus' titer $=[$ (mean titer after treatment mean titer prior to treatment)/mean titer prior to treatment] $\times 100$.

$\boldsymbol{P R}$ gene expression in leaves. Gene expression analyses were conducted for trials II and III. Leaf samples were taken from the same designated trees at five time points: $0,2,4,7$, and 14 days after the first trunk injection. At a given sampling time point, three sets of composite leaf samples representing three biological replicates per treatment were collected from three treated trees. A composite leaf sample consisting of eight leaves was randomly collected from an individual tree receiving plant defense activators or water. The leaf samples were wrapped in a prelabeled aluminum foil bag and immediately frozen in liquid nitrogen and stored at $-80^{\circ} \mathrm{C}$ until further analysis. Sixteen leaf discs $(0.90 \mathrm{~cm}$ in diameter) cut from eight leaves per sample using a cork borer were ground in liquid nitrogen to fine powder. Total RNA was isolated using the RNeasy mini kit for plants (Qiagen), following the manufacturer's instructions. RNA purification was conducted using the DNA-free DNase Treatment and Removal kit (Ambion). The quality and quantity of RNA samples were determined using a NanoDrop ND1000 spectrophotometer (NanoDrop Technologies). The concentration of RNA samples was adjusted to $25 \mathrm{ng} / \mu \mathrm{l}$ and an aliquot of $4 \mu \mathrm{l}$ of RNA sample ( $100 \mathrm{ng}$ ) was used in the following assay. The gene expression of $P R-1, P R-2, P R-3$, and $P R-15$ was quantified by a quantitative reverse-transcription (qRT)-PCR assay using one-step qScript qRT-PCR Kit (Quanta Bioscience) in an ABI PRISM 7500 sequence detection system. In total, three biological replicates from three treated trees were performed for each treatment. Each biological replicate was run in three separate PCR (three technical replicates). The housekeeping gene encoding glyceraldehyde-3-phosphate dehydrogenase-C (GAPDH-C) was used as an endogenous control. All primer sequences used in this study were specific to sweet orange (C. sinensis) and their origins and targets are summarized in Table 2.

Relative gene expression was computed using the $2^{-\Delta \Delta C t}$ method described by Livak and Schmittgen (2001). Briefly, the fold change in the target gene was normalized to plant GAPDH-C gene and relative to the expression at time 0 was calculated for each sample using the equation $\Delta \Delta C_{t}=\left(C_{t, \text { Target }}-C_{t, \text { GAPDH }}\right)_{\text {Time } x}-\left(C_{t, \text { Target }}-\right.$ $\left.C_{t, G A P D H}\right)_{\text {Time } 0}$, where time $x$ is any day after trunk injection of activators and time 0 is the time point when trunk injection was carried out.

Statistical analysis. The main effects of treatment and time on disease severity and ' $C a$. L. asiaticus' titer data in trial III were

TABLE 2. Target genes, their encoding protein, and corresponding primers used in gene expression analysis by quantitative reverse transcription polymerase chain reaction

\begin{tabular}{|c|c|c|c|}
\hline Target & Function of encoding protein & Primer-probe sequence $5^{\prime}-3^{\prime}$ & Reference \\
\hline CsPR1 & Antifungal and antioomycetic & $\begin{array}{l}\text { Forward: AACTCGCCTCAAGACTACCT } \\
\text { Reverse: TGCAACTGTGTCGTTCCATA }\end{array}$ & Dutt et al. (2015) \\
\hline CsPR2 & $\beta$-1,3-Glucanase & $\begin{array}{l}\text { Forward: TTCCACTGCCATCGAAACTG } \\
\text { Reverse: TGTAATCTTGTTTAAATGAGCCTCTTG }\end{array}$ & Francis et al. (2009) \\
\hline CsPR3 & Chitinase, antifungal & $\begin{array}{l}\text { Forward: TCCGACTACTGTGATCCTAACT } \\
\text { Reverse: TCTCCGCACCGTAAGTAATTG }\end{array}$ & Newly designed ${ }^{a}$ \\
\hline CsPR15 & Oxalate oxidase & $\begin{array}{l}\text { Forward: TGGTTTGAGCAAAGAGGGTAATA } \\
\text { Reverse: AGAGTATTGAGGCCAGGAAATG }\end{array}$ & Newly designed ${ }^{\mathrm{b}}$ \\
\hline
\end{tabular}

Reverse: CGTCCCTCTGCAAGATGACTCT

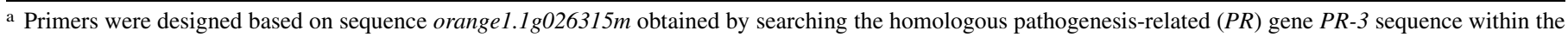
citrus genome.

b Primers were designed based on sequence 30147.m014037 obtained by searching the homologous $P R$ gene sequence within the citrus genome.
} 
analyzed using the MIXED procedure in SAS 9.3, with repeated measures best adjusted to heterogeneous autoregressive variance covariance structure of first order $(\alpha=0.05)$ (SAS Systems). Treatment comparisons for change in ' $\mathrm{Ca}$. L. asiaticus' titer, sAUDPS, fruit yield, juice quality parameters, and relative gene expression were analyzed by the general linear model procedure in SAS. To determine whether there were significant differences between treatments and the water-injected control, main effect means were calculated and a comparison for the main effects was performed using Dunnett's test (tested at $P<0.05$ ). All data in the graphs were presented as mean \pm standard error. Error bars represent standard error of mean ( $n=4$ in trials I and II and $n=10$ in trial III).

\section{RESULTS}

Effect of activators and antibiotic treatments on ' $\mathrm{Ca}$. $\mathrm{L}$. asiaticus' titer and HLB disease increase. A significant suppression effect of the injected compounds on both ' $\mathrm{Ca}$. L. asiaticus' titer and HLB disease development was observed in all three field trials. Although the degrees of ' $\mathrm{Ca}$. L. asiaticus' titer and disease suppression varied greatly among treatments, the three injected antibiotics and all activators except IMI and AA, in general, significantly reduced ' $\mathrm{Ca}$. L. asiaticus' titer in treated trees and substantially slowed the HLB disease progression as compared with water-injected control trees (Figs. 1, 2, and 3). Some activators exhibited significant ' $C a$. L. asiaticus'-diminishing effects. For example, whereas water-injected trees had 59.3 and $10.4 \%$ increase in ' $C a$. L. asiaticus' titer as well as 110 and $40 \%$ increase in disease severity, SA reduced ' $C a$. L. asiaticus' titer by 65.8 and $45.5 \%$ and provided 36.6 and $30.0 \%$ disease control (reduction in sAUDPS) in 5-year-old young trees in trials I and II, respectively (Fig. 1A and $1 \mathrm{~B}$ ). In trial III, SA initially lowered ' $\mathrm{Ca}$. L. asiaticus' titer (Fig. 3A) but ' $C a$. L. asiaticus' titer began to increase after reaching the bottom, whereas the combination of oxytetracycline and streptomycin had a long-lasting effect in suppressing ' $\mathrm{Ca}$. L. asiaticus' populations. SA also significantly reduced disease
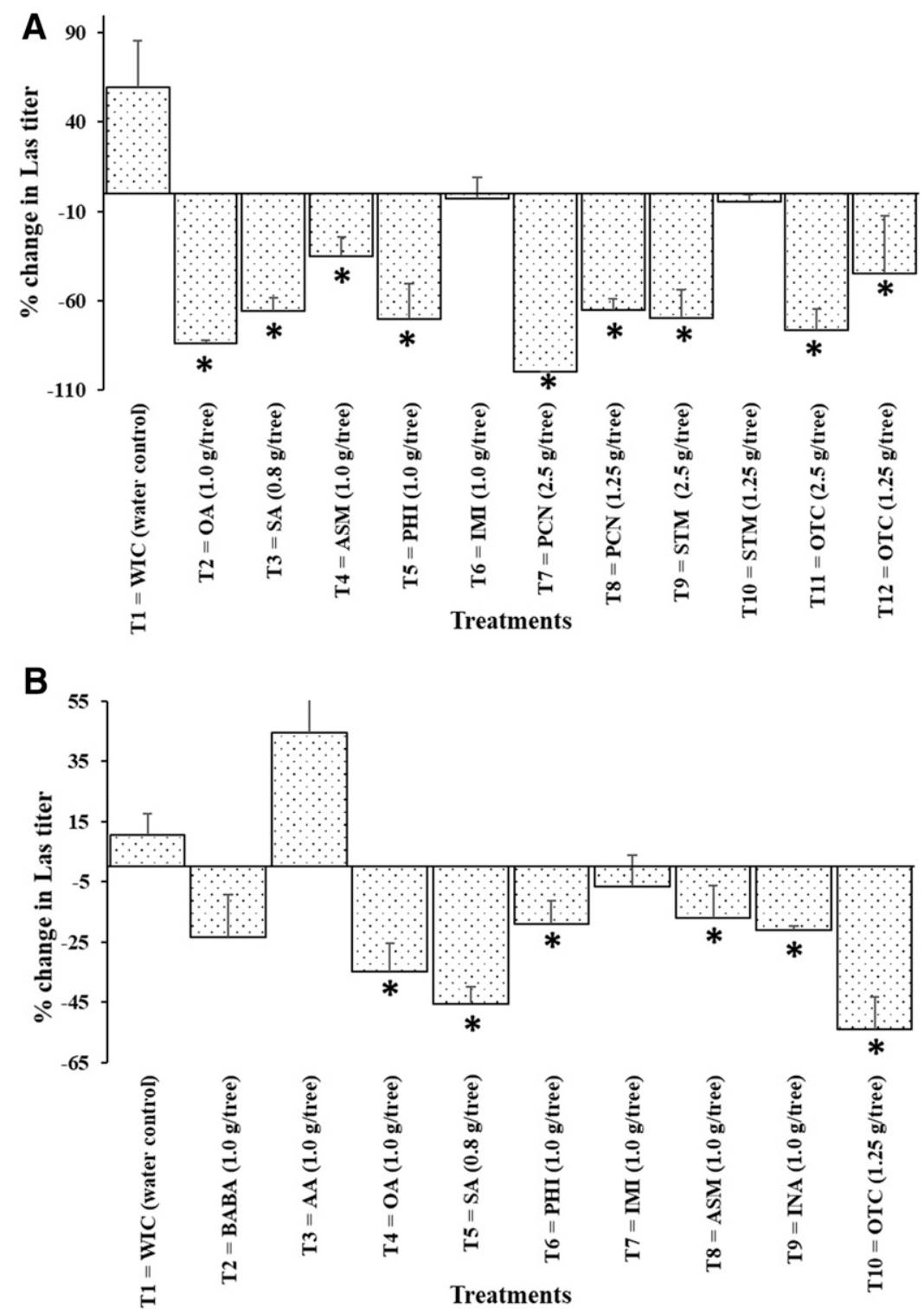

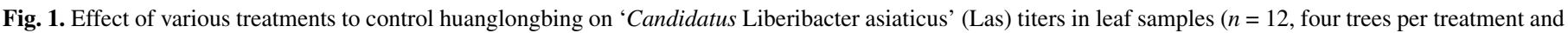

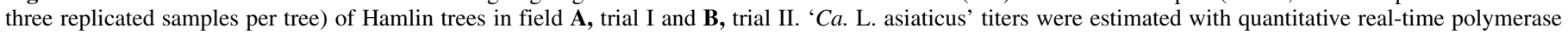

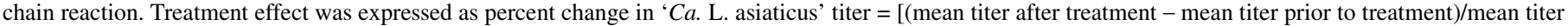

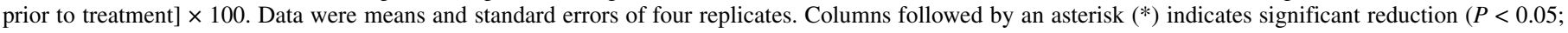

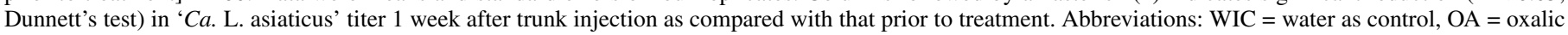

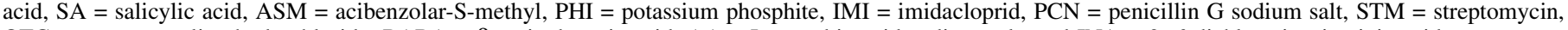
OTC $=$ oxytetracycline hydrochloride, BABA $=\beta$-aminobutyric acid, AA $=$ L-ascorbic acid sodium salt, and INA $=2$, 6-dichloro-isonicotinic acid. 
severity (Fig. 3B) in treated trees as compared with waterinjected control trees.

In trial I, the most effective compounds in suppression of ' $\mathrm{Ca}$. L. asiaticus' titer growth and disease development were PCN and OTC, followed by SA, OA, PHI, STM, and ASM (Figs. 1A and 2A). It is noteworthy that streptomycin at $1.25 \mathrm{~g} /$ tree had almost no effect in suppressing ' $\mathrm{Ca}$. L. asiaticus'. In contrast, little effect was observed with injected IMI. Similarly, in trial II, injected OTC provided the most effective disease control and significant reduction of ' $\mathrm{Ca}$. L. asiaticus' titer, followed by SA, OA, and ASM (Figs. 1B and $2 \mathrm{~B}$ ). On the other hand, there were no controlling effects of IMI and AA on the bacterial population or disease severity. At a higher HLB disease pressure, as indicated by disease severity of approximately 3.5 in mature trees at the beginning of trial III (Fig. 3B), a combination of OTC and STM at $1.2 \mathrm{~g}$ of each killed nearly all ' $C a$. L. asiaticus' in treated trees and revived HLB trees by greatly reducing disease severity as compared with before treatment. All four activators (i.e., SA, ASM, PHI, and OA) significantly reduced ' $\mathrm{Ca}$. L. asiaticus' titer and disease severity at the end of trial (Fig. 3A and B).
Effect of inducer and antibiotic treatments on yield and quality. In trial I, all three antibiotics significantly increased fruit yield (Fig. 2A), whereas fruit yield increase by all activators were not significant. In trial II, only oxytetracycline significantly increased fruit yield. In contrast, fruit yield increases were not significant in treatments of SA, PHI, ASM, and INA. In trial III with an 11-year-old Midsweet orange tree, the average weight of fruit per tree receiving treatments ranged from 46.7 to $51.7 \mathrm{~kg}$ whereas the water-injected control yielded $43.5 \mathrm{~kg} /$ tree (Fig. 3C; Table 3). Due to large variations among treated trees, such a yield increase of 7.4 to $18.9 \%$ by activator and antibiotic treatments was not statistically different from that of control trees. In general, all fruit quality parameters were within normal ranges and there were no significant differences between treatments and the water-injected control in most of the parameters. However, percent juice content was significantly higher in fruit from trees receiving injection of SA, ASM , and PHI (Table 3). In addition, trees treated with ASM and antibiotics OTC + STM showed a higher brix and brix/acidity ratio, indicating an increased level of sugar content.
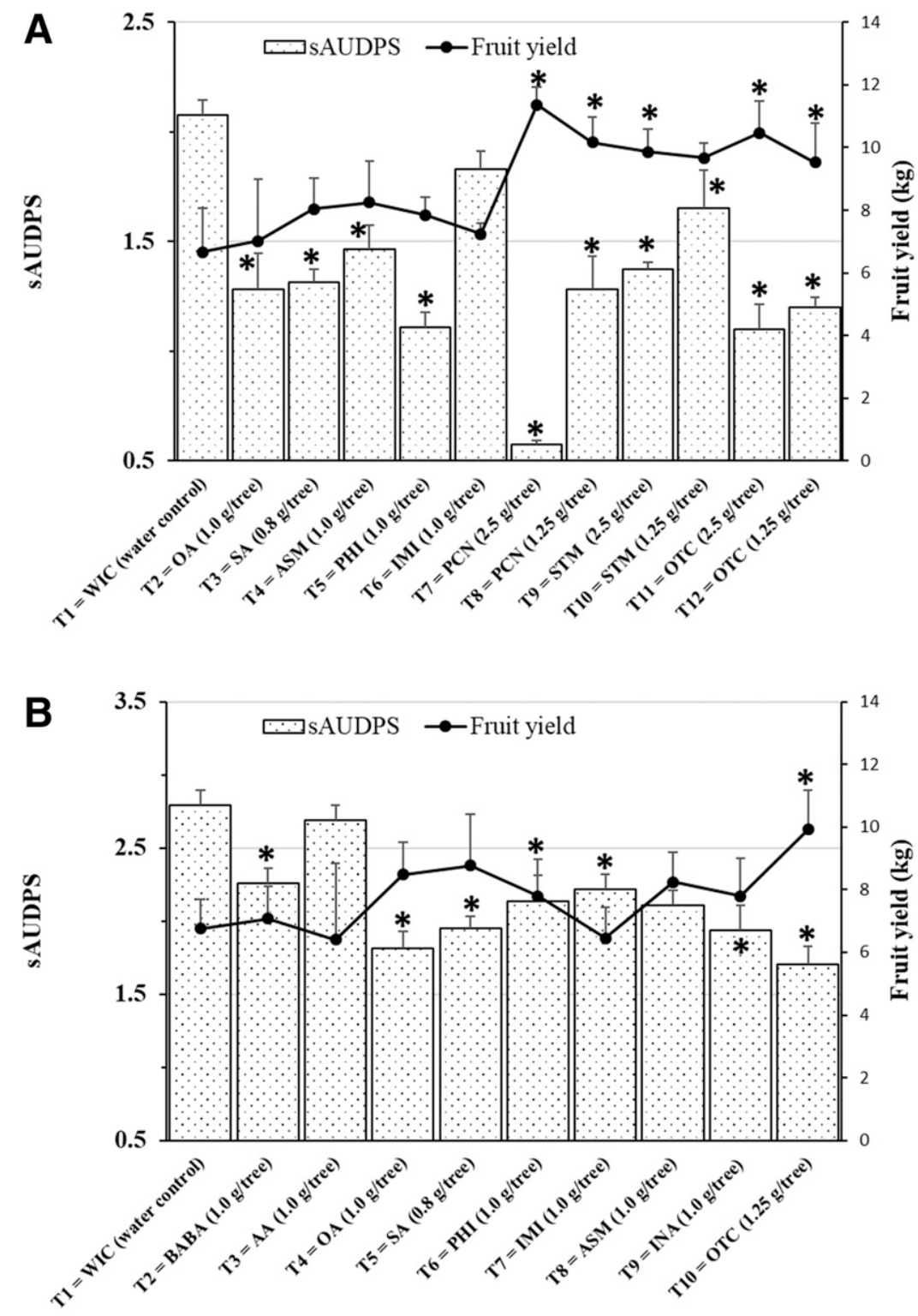

Fig. 2. Standardized area under the disease progress stairs (sAUDPS) for citrus huanglongbing and fruit yield in field A, trial I and B, trial II. Data were means and standard errors of four replicated trees. An asterisk (*) indicates significant difference $(P<0.05$; Dunnett's test) between the treatment and water-injected control. Abbreviations: $\mathrm{WIC}=$ water as control, OA = oxalic acid, SA = salicylic acid, ASM = acibenzolar-S-methyl, PHI = potassium phosphite, $\mathrm{IMI}=$ imidacloprid, $\mathrm{PCN}=$ penicillin $\mathrm{G}$ sodium salt, $\mathrm{STM}=$ streptomycin, $\mathrm{OTC}=$ oxytetracycline hydrochloride, $\mathrm{BABA}=\beta$-aminobutyric acid, $\mathrm{AA}=\mathrm{L}$-ascorbic acid sodium salt, and $\mathrm{INA}=2$, 6-dichloro-isonicotinic acid. 
$\boldsymbol{P R}$ gene expression in leaves. Different expression levels of $P R$ genes were induced when trunks were injected with $\mathrm{OA}$, SA, PHI, and ASM. When compared with the water-injected control, trunk injection of SA into citrus trees resulted in significant induction of $P R-1$, ranging from 2.6- to 3.5-fold change, and $P R-2$, ranging from 9.6- to 14.5-fold change at 2, 4, and 7 days after injection (Fig. 4A and B). Similarly, ASM injection led to significant induction of $P R-1$ of 2.9- to 4.1-fold change and $P R-2$ of 13.9- to 15.8-fold change at 2, 4, and 7 days after injection (Fig. $4 \mathrm{~A}$ and $\mathrm{B})$. PHI injection significantly induced $P R-2$ expression at
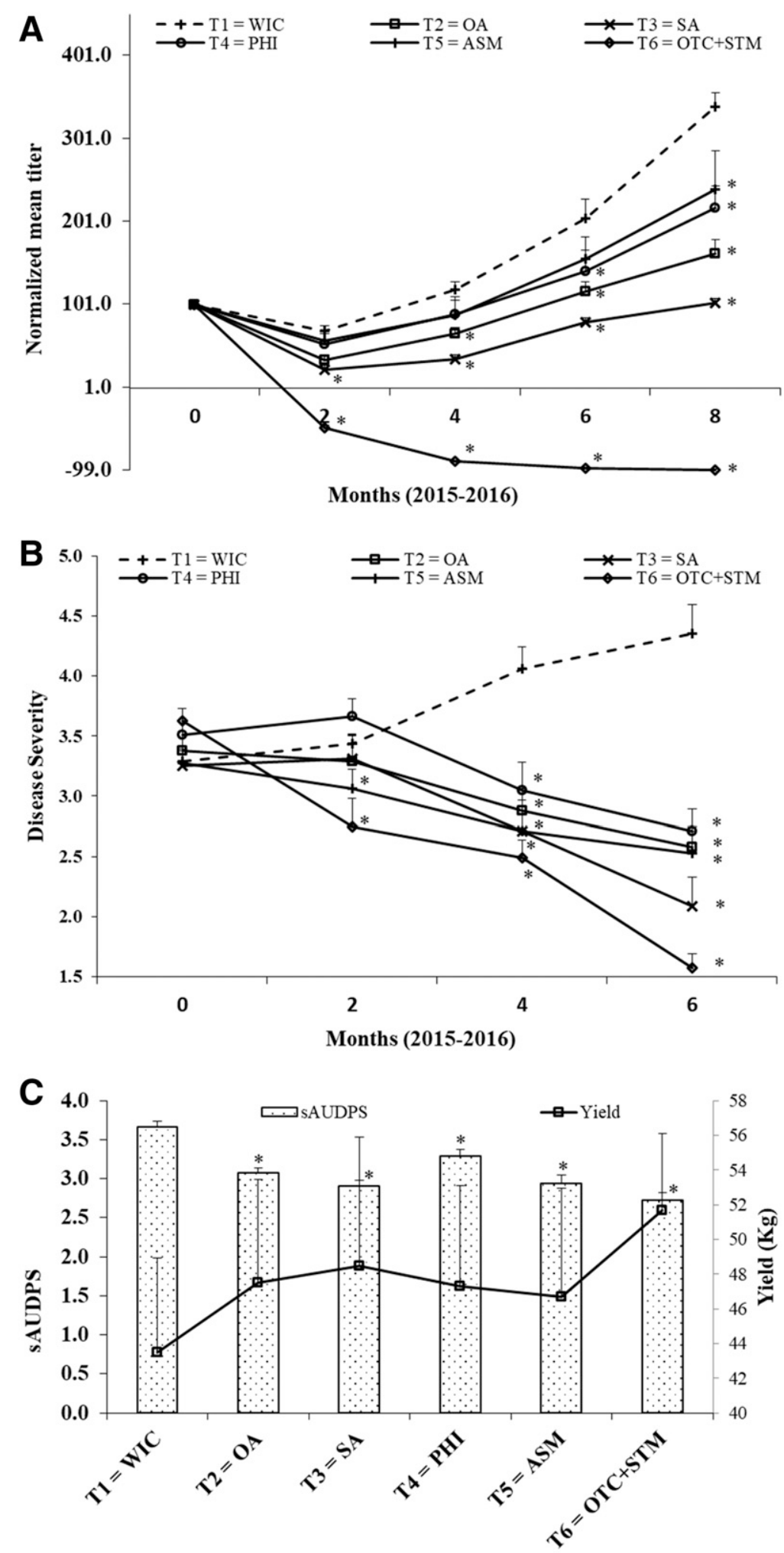

Treatments

Fig. 3. Effect of various treatments to control huanglongbing (HLB) of mature Hamlin trees in field trial III on A, 'Candidatus' Liberibacter asiaticus' titers in leaf samples $(n=10$ trees per treatment, three leaf samples per tree); $\mathbf{B}$, temporal dynamics of disease severity; and $\mathbf{C}$, standardized area under the disease progress stairs (sAUDPS) for citrus HLB and fruit yield. An asterisk (*) indicates significant difference $(P<0.05$; Dunnett's test) between the treatment and water-injected control $($ WIC) at a given time point. Abbreviations: $\mathrm{OA}=$ oxalic acid, $\mathrm{SA}=$ salicylic acid, $\mathrm{PHI}=$ potassium phosphite, $\mathrm{ASM}=$ acibenzolar-S-methyl, $\mathrm{OTC}=$ oxytetracycline hydrochloride, and STM = streptomycin. 
levels ranging from 5.3- to 11.8-fold change at 2, 4, and 7 days after injection (Fig. 4B). None of the four activators was able to induce $P R-3$ gene expression (Fig. 4C). Significant induction of $P R-15$ gene expression at levels from 3.4- to 5.5-fold change was observed with OA injection at 2, 4, and 7 days after injection (Fig. 4D). The temporal induction pattern was similar among $P R-1, P R-2$, and $P R-15$ in all treatments, with a peak expression level at 4 days after injection induction, which quickly diminished at 7 days after injection. At 14 days after injection, induction of $P R$ gene expressions in all treatments was reduced to a level similar to that of waterinjected control trees.

Trunk injection of activators and antibiotics. Although antibiotic compound OTC needs to be formulated for injection, PCN and STM were highly soluble in water and their aqueous solutions were suitable for trunk injection. Among eight plant defense activators tested in this study, five activators (i.e., AA, BABA, SA, OA, and PHI) were water soluble and their aqueous solutions can be easily delivered into the xylem via trunk injection. However, the uptake and transport of the remaining activators (i.e., ASM, IMI, and INA) was extremely slow through trunk injection due to their low solubility in water. For example, INA must first be dissolved in ethanol and then diluted to low concentrations with water. Therefore, injection-specific formulations for these three activators are required for higher dosages. In both trials I and III, no symptoms of chemical injury, stunting, and other abnormal appearance were observed over the course of 12 months in all trees receiving activators and antibiotics, indicating their lack of phytotoxic effect at concentrations tested. However, INA at rates of $1.0 \mathrm{~g} / \mathrm{tree}(5 \mathrm{mg} / \mathrm{ml}, 200 \mathrm{ml})$ caused chemical burns of leaf margins and dieback of young twigs on some branches of a young citrus tree, indicating that a much lower dosage is needed to alleviate their phytotoxic effects.

\section{DISCUSSION}

This study evaluated the control effect of trunk injection of plant defense activators and antibiotics against HLB. Harnessing a plant's induced resistance for practical disease control represents a sustainable approach to crop protection. In tree crops, attempts to transform this concept into consistent and adequate protection from pathogen attack has had limited success to date. Several field trials have demonstrated that the degree and magnitude of plant defense activators to activate plant defense weaponry against citrus canker and HLB varied greatly from limited to moderate efficacy under field conditions (Francis et al. 2009; Graham and Leite 2004; Li et al. 2016a). Among many factors responsible for such a varying and partial efficacy, application method of foliar spray and soil drench may be a significant limiting factor that results in poor absorption and translocation of activators in a citrus tree. In addition, plant defense activators such as ASM and SA are highly photodegradable and biodegradable (Silva et al. 2007; Sleiman et al. 2017) as well as vulnerable to other environmental conditions. Trunk injection of activators and antibiotics may avoid problems of degradation and poor absorption associated with foliar spray and soil drench. Overall, trunk injection of plant defense activators SA, ASM, OA, and PHI showed a positive control effect against HLB, even though it is much less than provided by antibiotics.

Injecting SA, ASM, OA, and PHI into HLB-diseased citrus induced expression of SAR-related $P R$ genes $P R-1,-2,-3$, and -15 . Similarly, injection of ASM and PHI into apple trees induced expression of $P R-1, P R-2$, and $P R-8$ genes and resistance against fire blight (Aćimović et al. 2015). It is well known that PR proteins are induced in many plant species in response to pathogens and inducing compounds and exhibit antimicrobial activities in vitro (Walters and Fountaine 2009). For example, PR-1 protein had inhibitory activities against oomycetes and inhibited the differentiation of infection hyphae in leaves of acquired resistant broad bean (Alexander et al. 1993; Rauscher et al. 1999). PR-2 protein exhibits $\beta$-1,3-glucanase with hydrolase activity on cell walls of fungi and oomycetes (Mauch et al. 1988). Whether induction of $P R-1$ and $P R$ 2 contributes to resistance against HLB remains unknown. On the other hand, PR-3 protein exhibits chitinolytic activity against the bacterial pathogen of apple fire blight (Maxson-Stein et al. 2002). PR15 protein is oxalate oxidase inducible during seed germination and pathogen infection of many crops (Ferreira et al. 2007). In this study, we found that OA significantly induced expression of the $P R-15$ gene. OA is a key pathogenicity factor in several fungal species, including Sclerotinia spp., and oxalate oxidase can break down OA into carbon dioxide and hydrogen peroxide (Bernier and Berna 2001). Hydrogen peroxide is a signaling molecule involved in plant defense mechanisms. $P R-15$ gene homologs are present in citrus and, thus, OA may be a good inducing agent for high-level expression of $P R-15$ gene. It is important to note that some of these plant defense-inducing compounds under certain conditions may have direct antimicrobial activities at high concentrations. For example, SA has antifungal activity against Penicillium expansum (Da Rocha Neto et al. 2015). OA has strong antibacterial activity against nine plant-pathogenic bacteria, including Ralstonia solanacearum (Kwak et al. 2016). Hexanoic acid, a natural compound activator, inhibited growth of Botrytis cinerea (Leyva et al. 2008). Therefore, the question of how plant defense activators lead to ' $\mathrm{Ca}$. L. asiaticus' suppression in injected trees remains to be investigated.

Trunk injection of plant defense activators and antibiotics effectively prolonged life and maintained the yields of HLBinfected trees. Our field studies indicated that induced resistance by trunk-injected SA, ASM, OA, and PHI had some positive impact on fruit yield and quality. This result is in agreement with results from earlier studies on induced resistance by foliar spray of plant defense inducers in citrus ( $\mathrm{Li}$ et al. 2016a, 2017). However, it has been speculated that induced resistance may be costly because of metabolic competition between processes involved in plant growth and the synthesis of defense-related compounds. There are few

TABLE 3. Yield and quality of Midsweet orange fruit harvested from field trial III

\begin{tabular}{|c|c|c|c|c|c|}
\hline \multirow[b]{2}{*}{ Treatment ${ }^{\mathrm{b}}$} & \multirow[b]{2}{*}{ Yield (kg/tree) } & \multicolumn{4}{|c|}{ Fruit quality ${ }^{\mathrm{a}}$} \\
\hline & & Juice (\%) & Brix & Acidity & Brix/acidity \\
\hline $\mathrm{T} 1=\mathrm{WIC}$ & 43.5 & 53.49 & 11.51 & 0.49 & 23.44 \\
\hline $\mathrm{T} 2=\mathrm{OA}$ & 47.5 & 55.00 & 12.24 & 0.52 & 23.39 \\
\hline $\mathrm{T} 4=\mathrm{PHI}$ & 47.3 & $57.58 *$ & 11.66 & 0.51 & 22.99 \\
\hline $\mathrm{T} 5=\mathrm{ASM}$ & 46.7 & $58.39 *$ & $12.39 *$ & 0.52 & $25.28 *$ \\
\hline $\mathrm{T} 6=\mathrm{OTC}+\mathrm{STM}$ & 51.7 & 55.35 & $13.37 *$ & 0.51 & $26.29 *$ \\
\hline
\end{tabular}

a Approximately $8 \mathrm{~kg}$ of composite fruit sample was taken from each tree for juice quality analysis according to standard methods (Gottwald et al. 2012). Each value was the mean of 10 replicated trees per treatment. Values followed by an asterisk (*) indicate significant difference between treatment and control $(P<0.05$, Dunnett's test $)$.

b $\mathrm{WIC}=$ water as control, $\mathrm{OA}=$ oxalic acid, $\mathrm{SA}=$ salicylic acid, $\mathrm{PHI}=$ potassium phosphite, $\mathrm{ASM}=$ acibenzolar-S-methyl, OTC $=$ oxytetracycline hydrochloride, and STM $=$ streptomycin; OTC + STM $=1.2 \mathrm{~g}$ of OTC $+1.2 \mathrm{~g}$ of STM per tree. 
reports of such costs of induced resistance on wild plants or crops (Cipollini et al. 2003). Heil et al. (2000) showed that healthy wheat treated with BTH (synonym of ASM) had lower numbers of ears and grains as well as plant biomass, especially when these treated plants were under nitrogen stress. Therefore, we believe that a good nutritional program is important to avoid stressful conditions when treating HLB-infected citrus with activators, because stressful conditions on HLB-infected trees may inflict yield costs. Additionally, ' $C a$. L. asiaticus' encodes a functional SA hydroxylase that degrades SA, thus affecting its ability to induce plant
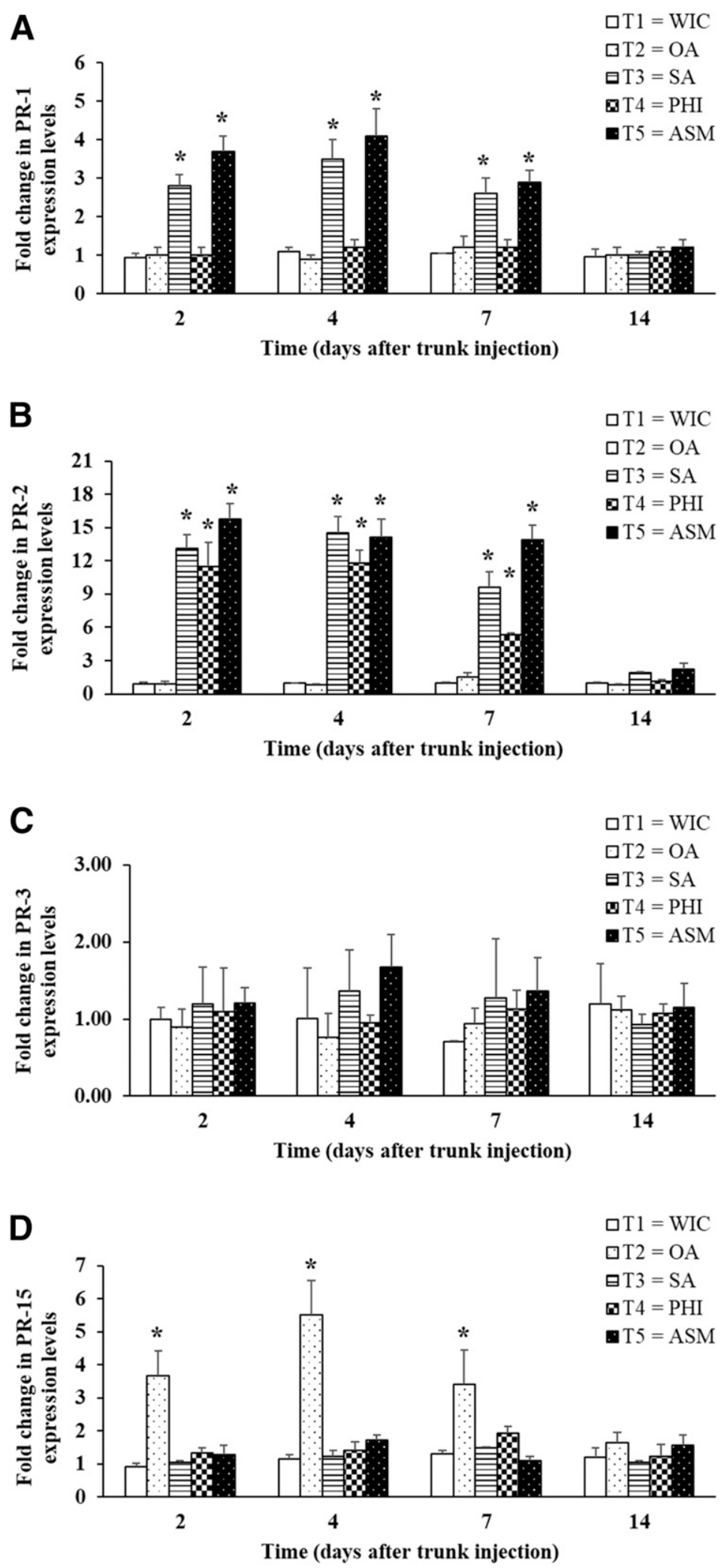

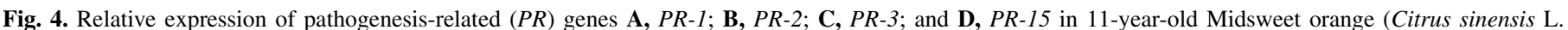

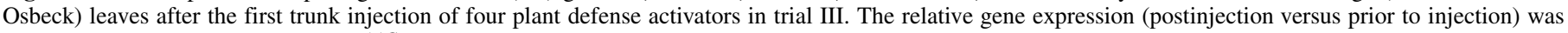

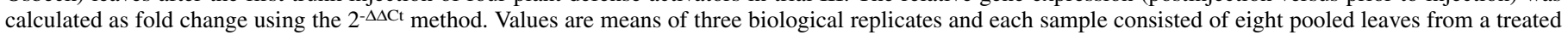

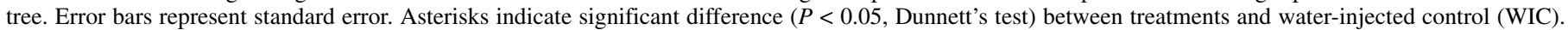
Abbreviations: $\mathrm{OA}=$ oxalic acid, $\mathrm{SA}=$ salicylic acid, $\mathrm{PHI}=$ potassium phosphite, and ASM = acibenzolar-S-methyl. 
defenses (Li et al. 2017). Trunk injection of SA seems to be able to overcome the SA degradation by the enzyme.

Trunk-injected antibiotics had better performance than injected activators in reducing ' $\mathrm{Ca}$. L. asiaticus' bacterium and increasing fruit yield in an HLB-infected tree. The antimicrobials induced by plant defense inducers might not reach the same high concentration and same effectiveness as injected antibiotics. In addition, ' $\mathrm{Ca}$. L. asiaticus' encodes one SA hydroxylase that degrades SA and suppresses plant defenses (Li et al. 2017). Injected OTC, PCN, and STM provided excellent control of citrus HLB severity by substantial reduction of ' $\mathrm{Ca}$. L. asiaticus' titers in HLB-diseased plants (Figs. 1A and 3A). By combining STM (bactericidal) and OTC (bacteristatic) into a single treatment, $99 \%$ reduction in ' $C a$. L. asiaticus' titer was achieved in field trial III. Such a dramatic inhibitory effect on ' $\mathrm{Ca}$. L. asiaticus' populations may be due to the synergistic effect between OTC and STM. A synergistic effect of OTC and STM was well documented on several bacterial species, including plant-pathogenic bacteria (Novy et al. 2011; Richardson and Holt 1962; Sabet 1956). It is noteworthy to point out that the qPCR method used in this study underestimated treatment effect on ' $\mathrm{Ca}$. L. asiaticus' titers because it does not differentiate live bacterial cells from dead ones. From the perspective of epidemiology, the substantial reduction of ' $\mathrm{Ca}$. L. asiaticus' titers in a 'Ca. L. asiaticus'-infected tree will significantly lower the likelihood of inoculum spread among neighboring trees in a citrus grove, because ' $C a$. L. asiaticus' acquisition by psyllids positively correlates with bacterial concentration in the host plant (Coletta-Filho et al. 2014). Trunk injection of antibiotics is capable of delivering a large dose to phloem vessels of stem and root tissues where ' $\mathrm{Ca}$. L. asiaticus' titers reside. Our previous study demonstrated that trunk injection of OTC resulted in quick translocation and uniform distribution of OTC across the entire plant, including root systems, and a low level of residue in fruit (Hu and Wang 2016). Many studies have examined streptomycin residues on apple and pear trees, whereas fewer have addressed residues of oxytetracycline. All earlier studies demonstrated that fruit from trees treated with streptomycin or oxytetracycline for fire blight management does not have residues near the tolerance levels permitted by governmental agencies (Gardan and Manceau 1984; Shaffer and Goodman 1969; Stockwell and Duffy 2012; Stockwell et al. 2008). The amount of antibiotic in positive apple and citrus was far below the minimum inhibitory concentration for gut flora, strongly suggesting that any antibiotics transferred to the gut would have negligible impacts on gut flora.

Given the epidemic status of citrus HLB in Florida, a multifaceted HLB management program is urgently needed for saving HLBinfected trees and prolonging their productivity. Trunk injection of antibiotics or plant defense activators may provide a useful tool for the citrus growers in the battle against citrus HLB in Florida if the residue level in juice due to injection is negligible. In addition, current injection technology and equipment is labor intensive and costly and may not be able to scale up to cope with hundreds of thousands of ' $C a$. L. asiaticus'-infected trees. Development of an automated trunk injection system with high efficiency is needed for large-scale application in commercial agricultural settings.

\section{ACKNOWLEDGMENTS}

This research has been supported by the Citrus Initiative.

\section{LITERATURE CITED}

Aćimović, S., Zeng, Q., McGhee, G., Sundin, G., and Wise, J. 2015. Control of fire blight (Erwinia amylovora) on apple trees with trunk-injected plant resistance inducers and antibiotics and assessment of induction of pathogenesis-related protein genes. Front. Plant Sci. 6:16.

Agostini, J., Bushong, P., and Timmer, L. 2003. Greenhouse evaluation of products that induce host resistance for control of scab, melanose, and Alternaria brown spot of citrus. Plant Dis. 87:69-74.
Alexander, D., Goodman, R., Gutrella, M., Glascock, C., Weymann, K., Friedrich, L., Maddox, D., Ahlgoy, P., Luntz, T., Ward, E., and Ryals, J. 1993. Increased tolerance to 2 oomycete pathogens in transgenic tobacco expressing pathogenesis-related protein-1a. Proc. Natl. Acad. Sci. USA 90: 7327-7331.

Aranega-Bou, P., Leyva, M., Finiti, I., Garcia-Agustin, P., and Gonzalez-Bosch, C. 2014. Priming of plant resistance by natural compounds. Hexanoic acid as a model. Front. Plant Sci. 5:488.

Bernier, F., and Berna, A. 2001. Germins and germin-like proteins: Plant do-all proteins. But what do they do exactly? Plant Physiol. Biochem. 39:545-554.

Boina, D., and Bloomquist, J. 2015. Chemical control of the Asian citrus psyllid and of huanglongbing disease in citrus. Pest Manage. Sci. 71:808-823.

Bove, J. 2006. Huanglongbing: A destructive, newly-emerging, century-old disease of citrus. J. Plant Pathol. 88:7-37.

Buzi, A., Chilosi, G., and Magro, P. 2004. Induction of resistance in melon seedlings against soil-borne fungal pathogens by gaseous treatments with methyl jasmonate and ethylene. J. Phytopathol. 152:491-497.

Cipollini, D., Purrington, C., and Bergelson, J. 2003. Costs of induced responses in plants. Basic Appl. Ecol. 4:79-89.

Coletta-Filho, H. D., Daugherty, M. P., Ferreira, C., and Lopes, J. R. S. 2014. Temporal progression of 'Candidatus Liberibacter asiaticus' infection in citrus and acquisition efficiency by Diaphorina citri. Phytopathology 104:416-421.

da Graca, J. V., and Korsten, L. 2004. Citrus huanglongbing: Review, present status and future strategies. Pages 229-245 in: Diseases of Fruits and Vegetables. S. A. M. H. Naqui, ed. Kluwer Academic Publishers, Dordrecht, The Netherlands.

da Rocha Neto, A. C., Maraschin, M., and Di Piero, R. M. 2015. Antifungal activity of salicylic acid against Penicillium expansum and its possible mechanisms of action. Int. J. Food Microbiol. 215:64-70.

Dekkers, M., Graham, J., Burns, J., Cubero, J., and Colburn, G. 2004. Evaluation of chemical inducers and PR protein reporters for induced systemic resistance to citrus bacterial diseases. (Abstr.) Phytopathology 94:S25.

Dutt, M., Barthe, G., Irey, M., and Grosser, J. 2015. Transgenic citrus expressing an Arabidopsis NPR1 gene exhibit enhanced resistance against huanglongbing (HLB; citrus greening). PLoS One 10:e0137134.

Ferreira, R., Monteiro, S., Freitas, R., Santos, C., Chen, Z., Batista, L., Duarte, J., Borges, A., and Teixeira, A. 2007. The role of plant defence proteins in fungal pathogenesis. Mol. Plant Pathol. 8:677-700.

Francis, M., Redondo, A., Burns, J., and Graham, J. 2009. Soil application of imidacloprid and related SAR-inducing compounds produces effective and persistent control of citrus canker. Eur. J. Plant Pathol. 124:283-292.

Gardan, L., and Manceau, C. 1984. Persistence of streptomycin in pear and apple tissue. Acta Hortic. 151:179-186.

Gottwald, T. R., da Graca, J. V., and Bassanezi, R. B. 2007. Citrus huanglongbing: The pathogen and its impact. Online publication. Plant Health Prog. doi.org/10.1094/PHP-2007-0906-01-RV

Gottwald, T. R., Graham, J. H., Irey, M. S., McCollum, T. G., and Wood, B. W. 2012. Inconsequential effect of nutritional treatments on huanglongbing control, fruit quality, bacterial titer and disease progress. Crop Prot. 36:73-82.

Graham, J., and Leite, R. 2004. Lack of control of citrus canker by induced systemic resistance compounds. Plant Dis. 88:745-750.

Graham, J., and Myers, M. 2011. Soil application of SAR inducers imidacloprid, thiamethoxam, and acibenzolar-S-methyl for citrus canker control in young grapefruit trees. Plant Dis. 95:725-728.

Halbert, S., and Manjunath, K. 2004. Asian citrus psyllids (Sternorrhyncha: Psyllidae) and greening disease of citrus: A literature review and assessment of risk in Florida. Fla. Entomol. 87:330-353.

Heil, M., Hilpert, A., Kaiser, W., and Linsenmair, K. 2000. Reduced growth and seed set following chemical induction of pathogen defence: Does systemic acquired resistance (SAR) incur allocation costs? J. Ecol. 88: 645-654.

Hoffman, M., Doud, M., Williams, L., Zhang, M., Ding, F., Stover, E., Hall, D., Zhang, S., Jones, L., Gooch, M., Fleites, L., Dixon, W., Gabriel, D., and Duan, Y. 2013. Heat treatment eliminates 'Candidatus Liberibacter asiaticus' from infected citrus trees under controlled conditions. Phytopathology 103:15-22.

Hu, J., and Wang, N. 2016. Evaluation of the spatiotemporal dynamics of oxytetracycline and its control effect against citrus huanglongbing via trunk injection. Phytopathology 106:1495-1503.

Justyna, P., and Ewa, K. 2013. Induction of resistance against pathogens by $\beta$-aminobutyric acid. Acta Physiol. Plant. 35:1735-1748.

Kwak, A., Lee, I., Lee, S., Yun, B., and Kang, H. 2016. Oxalic acid from Lentinula edodes culture filtrate: Antimicrobial activity on phytopathogenic bacteria and qualitative and quantitative analyses. Microbiology 44: 338-342.

Leyva, M., Vicedo, B., Finiti, I., Flors, V., Del Amo, G., Real, M., Garcia-Agustin, P., and Gonzalez-Bosch, C. 2008. Preventive and postinfection control of Botrytis cinerea in tomato plants by hexanoic acid. Plant Pathol. 57:1038-1046. 
Li, J. Pang, Z., Trivedi, P., Zhou, X., Ying, X., Jia, H., Wang N. 2017 'Candidatus Liberibacter asiaticus' encodes a functional salicylic acid (SA) Hydroxylase that degrades SA to suppress plant defenses. Mol. PlantMicrobe Interact. 30:620-630.

Li, J., Trivedi, P., and Wang, N. 2016a. Field evaluation of plant defense inducers for the control of citrus huanglongbing. Phytopathology 106:37-46.

Livak, K., and Schmittgen, T. 2001. Analysis of relative gene expression data using real-time quantitative PCR and the $2^{-\Delta \Delta C T}$ method. Methods 25: 402-408.

Mauch, F., Mauchmani, B., and Boller, T. 1988. Antifungal hydrolases in pea tissue. II. Inhibition of fungal growth by combinations of chitinase and B-1,3-glucanase. Plant Physiol. 88:936-942.

Maxson-Stein, K., He, S., Hammerschmidt, R., and Jones, A. 2002. Effect of treating apple trees with acibenzolar-S-methyl on fire blight and expression of pathogenesis-related protein genes. Plant Dis. 86:785-790.

Mersha, Z., Zhang, S., and Raid, R. 2012. Evaluation of systemic acquired resistance inducers for control of downy mildew on basil. Crop Prot. 40: 83-90.

Mirkov, T. E., and Gonzalez-Ramos, J. 2013. Pathogen resistant citrus compositions, organisms, systems, and methods. Patent Application WO 2013112997 A1 and US 20130205443 A1.

Novy, P., Urban, J., Leuner, O., Vadlejch, J., and Kokoska, L. 2011. In vitro synergistic effects of baicalin with oxytetracycline and tetracycline against Staphylococcus aureus. J. Antimicrob. Chemother. 66:1298-1300.

Obanor, F., Walter, M., Jones, E., and Jaspers, M. 2013. Efficacy of systemic acquired resistance inducers in olive leaf spot management. Australas. Plant Pathol. 42:163-168

Oren, Y., and Yogev, E. 2002. Acquired resistance to Phytophthora root rot and brown rot in citrus seedlings induced by potassium phosphite. J. Plant Dis. Prot. 109:279-285.

Perez, L., Rodriguez, M., Rodriguez, F., and Roson, C. 2003. Efficacy of acibenzolar-S-methyl, an inducer of systemic acquired resistance against tobacco blue mould caused by Peronospora hyoscyami f. sp. tabacina. Crop Prot. 22:405-413.

Rauscher, M., Adam, A., Wirtz, S., Guggenheim, R., Mendgen, K., and Deising, H. 1999. PR-1 protein inhibits the differentiation of rust infection hyphae in leaves of acquired resistant broad bean. Plant J. 19:625-633.

Richardson, M., and Holt, J. 1962. Synergistic action of streptomycin with other antibiotics on intracellular Brucella abortus in vitro. J. Bacteriol. 84: 638-646.
Sabet, K. 1956. The effects of streptomycin and terramycin, singly and in combination, on the leaf blight disease of maize caused by Bacterium carotovoruum F. zeae sabet. Ann. Appl. Biol. 44:152-160.

Shaffer, W. H., and Goodman, R. N. 1969. Effectiveness of an extended agrimycin-17 spray schedule against fire blight. Plant Dis. Rep. 53:669-672.

Silva, T., Valdman, E., Valdman, B., and Leite, S. 2007. Salicylic acid degradation from aqueous solutions using Pseudomonas fluorescens HK44: Parameters studies and application tools. Braz. J. Microbiol. 38:39-44.

Simko, I., and Piepho, H. 2012. The area under the disease progress stairs: Calculation, advantage, and application. Phytopathology 102:381-389.

Sleiman, M., Stawinoga, M., Wang, S., de Sainte-Claire, P., Goupil, P., and Richard, C. 2017. Photochemical transformation of the plant activator acibenzolar-S-methyl in solution. J. Photochem. Photobiol. 333:79-86.

Stansly, P., Arevalo, H., Qureshi, J., Jones, M., Hendricks, K., Roberts, P., and Roka, F. 2014. Vector control and foliar nutrition to maintain economic sustainability of bearing citrus in Florida groves affected by huanglongbing. Pest Manage. Sci. 70:415-426.

Stockwell, V. O., and Duffy, B. 2012. Use of antibiotics in plant agriculture. Rev. Sci. Tech. Off. Int. Epiz. 31:199-210.

Stockwell, V. O., Temple, T. N., Johnson, K. B., and Loper, J. E. 2008. Integrated control of fire blight with antagonists and oxytetracycline. Acta Hortic. 793:383-390.

Trivedi, P., Sagaram, U. S., Kim, J. S., Brlansky, R. H., Rogers, M. E., Stelinski, L. L., Oswalt, C., and Wang, N. 2009. Quantification of viable 'Candidatus Liberibacter asiaticus' in hosts using quantitative PCR with the aid of ethidium monoazide (EMA). Eur. J. Plant Pathol. 124:553-563.

Vallad, G., and Goodman, R. 2004. Systemic acquired resistance and induced systemic resistance in conventional agriculture. Crop Sci. 44:1920-1934.

Walters, D., and Fountaine, J. 2009. Practical application of induced resistance to plant diseases: An appraisal of effectiveness under field conditions. J. Agric. Sci. 147:523-535.

Walters, D., Ratsep, J., and Havis, N. 2013. Controlling crop diseases using induced resistance: Challenges for the future. J. Exp. Bot. 64:1263-1280.

Wang, Z., Yin, Y., Hu, H., Yuan, Q., Peng, G., and Xia, Y. 2006. Development and application of molecular-based diagnosis for 'Candidatus Liberibacter asiaticus', the causal pathogen of citrus huanglongbing. Plant Pathol. 55: 630-638.

Zhang, M., Guo, Y., Powell, C., Doud, M., Yang, C., and Duan, Y. 2014. Effective antibiotics against 'Candidatus Liberibacter asiaticus' in HLB-affected citrus plants identified via the graft-based evaluation. PLoS One 9:e111032. 